\title{
Enkulturasi Nilai Karakter Melalui Permainan Tradisional Pada Pembelajaran Tematik Di Sekolah Dasar
}

\author{
Ani Siti Anisah ${ }^{1)}$, Ade Holis ${ }^{2)}$ \\ Universitas Garut \\ sitianisah@uniga.ac.id ${ }^{1)}$, adeholis@uniga.ac.id ${ }^{2)}$
}

\begin{abstract}
Abstrak
Proses penanaman karakter di sekolah selama ini berlangsung secara tidak langsung sehingga berdampak kepada kurang terbangunnya karakter peserta didik. Didukung oleh perkembangan teknologi yang melahirkan berbagai inovasi telah menggeser nilai-nilai budaya yang dianut masyarakat dan melemahkan kekuatan karakter bangsa. Lembaga pendidikan memiliki peran dalam memperbaiki lemahnya sumber daya manusia terutama karakter, bahkan tripusat pendidikan harus bersinergi dalam membangun karakter peserta didik sejak dini. Pendidikan tingkat dasar merupakan akar pendidikan yang paling mendasar sehingga keberhasilannya sangat menentukan proses belajar peserta didik pada jenjang selanjutnya. Pemberlakuan Kurikulum 2013 salah satunya bertujuan untuk memperbaiki karakter peserta didik. Pembelajaran tematik integrative diterapkan dengan mengaitkan berbagai mata pelajaran yang ada dengan permasalahan-permasalahan yang dijumpai di sekitar sehingga pembelajaran menjadi kontekstual dengan konsep belajar learning by doing. Disamping itu pendidik dituntut kreatif dalam mengembangkan bahan ajar, memilih sumber dan media belajar yang tersedia di lingkungan sekitar. Proses mempelajari nilai budaya local dapat dilakukan melalui pembelajaran tematik agar terjadi proses enkulturasi nilai karakter, karena proses enkulturasi merupakan proses alamiah yang terjadi di lingkungan pendidikan baik formal, informal maupun non formal. Pada pendidikan formal pendidik dituntut untuk memperhatikan karakteristik peserta didik usia sekolah dasar sehingga pendidik harus lebih kreatif dalam mengembangkan pembelajaran yang mengandung unsur permainan, menciptakan lingkungan teman sebaya yang mengajarkan keterampilan fisik, bersosialisasi, bekerjasama, kontekstual, dan mampu mengembangkan nilai karakter selama proses pembelajaran.
\end{abstract}

Kata Kunci: Enkulturasi; Nilai-nilai Karakter; Permainan Tradisional; Pembelajaran Tematik; Sekolah Dasar 


\section{Pendahuluan}

Berkembanganya ilmu pengetahuan dan teknologi era Revolusi Industri 4.0 menghasilkan inovasi yang secara fundamental telah merubah cara berfikir dan beraktivitas manusia serta memberikan pengaruh yang besar terhadap kepribadian manusia itu sendiri, bahkan wujud dunia menurut Satya (2018) telah berubah menjadi kampung global.

Kondisi bangsa Indonesia saat ini mengalami krisis multidimensi (Muhtar, 2014; Ainissyifa, 2014) seperti menurunnya penghargaan terhadap nilai budaya bangsa, rasa cinta tanah air yang memudar, etika sopan santun terhadap orang tua, guru, teman sebaya, lunturnya nilai-nilai kerjasama atau gotong royong karena mengedepankan kehidupan individualistis, tatanan kehidupan sosial yang lemah akan nilai-nilai kemanusiaan dan nilai-nilai religious yang berdampak pada sumber daya manusia rendah karena lemahnya modal sosial (Maryani, E; Syamsudin, 2009).

Problematika diatas merupakan rujukan bagi semua elemen masyarakat agar melakukan upaya enkulturasi nilai karakter agar bisa mengembalikan jatidiri bangsa. Untuk mempersiapkan persoalan tersebut, pendidikan adalah salah satu solusi terbaik mempersiapkan SDM dalam menghadapi tantangan global di era 4.0 yang tidak hanya membekali pengetahuan teknologi tetapi juga pengetahuan tentang manusia itu sendiri. Ilmu teknologi perlu dipelajari, tetapi yang terpenting adalah bagaimana menanamkan nilai-nilai untuk membentuk manusia berkarakter agar bijak menggunakan teknologi saat ini dan masa yang akan datang tanpa menghilangkan tradisi budayanya sendiri.

Peraturan Presiden No 87 Tahun 2017 dan Permendikbud No 20 tahun 2018 tentang Penguatan Pendidikan Karakter sebagai sebuah gerakan pada satuan pendidikan berusaha memperkuat karakter peserta didik dengan melakukan harmonisasi olah hati, olah rasa, olah fikir, dan olah raga dengan melibatkan kerjasama antar satuan pendidikan, keluarga, dan masyarakat. Didukung oleh Kurikulum 2013 yang dirancang untuk menanamkan nilai-nilai karakter dengan tujuan untuk mengubah sikap pembelajar agar lebih santun dan memahami melalui nilai-nilai karakter yang terkandung di dalamnya. Penelitian Pramudiyani (2017) menjelaskan bahwa kurikulum 2013 dengan pembelajaran tematik memudahkan pedidik lebih leluasa dalam menyusun rencana pembelajaran, bahkan pembelajaran tematik integrative (Ariyanti, 2017) guru lebih kreatif dalam memanfaatkan lingkungan sekitar sebagai sumber belajar, dengan demikian kesempatan peserta didik dalam mempelajari nilai karakter semakin besar dengan demikianTripusat pendidikan harus bersinergi dalam melaksanakan program pendidikan yang terarah sesuai dengan tujuan pendidikan (Kurniawan, 2015), kemudian membangun sistem pendidikan yang mampu mempersiapkan peserta didik untuk memiliki keterampilan dalam menghadapi tantangan global di berbagai bidang tanpa menghilangkan berbagai unsur kearifan lokal, tradisi dan pranata lokal, termasuk norma dan adat istiadat yang bermanfaat, 
sehingga dapat berfungsi secara efektif dalam pendidikan karakter, sambil melakukan kajian dan pengayaan dengan kearifan-kearifan baru Sartini (2014).

Peraturan Presiden dan Permendikbud diatas dinilai memayungi pelaksanaan pembelajaran tematik berbasis budaya local, menjadi panduan lembaga pendidikan dalam mengembangkan karakter peserta didik. Kreativitas guru dituntut untuk menyeimbangkan antara pengetahuan dan teknologi dengan unsur budaya bangsa untuk meningkatkan jiwa nasionalisme pada diri peserta didik (Artobatama, 2018).

Tulisan ini difokuskan pada bagaimana proses mempelajari nilai karakter dalam pembelajaran tematik melalui Permainan Tradisional di Sekolah Dasar/MI. Bagaimana karakter itu terbangun sehingga peserta didik bisa mempelajari nilai karakter sebagi bekal hidupnya dimasa depan.

\section{Metodologi Penelitian}

Metode yang digunakan dalam penulisan ini adalah dengan studi pustaka. Penulis mengumpulkan beberapa sumber primer dari beberapa referensi baik jurnal hasil penelitian maupun buku-buku yang relevan dan didukung oleh data sekunder.

\section{Hasil Dan Pembahasan \\ Enkulturasi Nilai Karakter}

Enkulturasi merupakan bagian dari konsep dinamika kebudayaan sebagai sebuah proses belajar kebudayaan sendiri (Koenjtaraningrat, 1996). Dalam dunia pendidikan, enkulturasi merupakan upaya mempertahankan keberlangsungan sekelompok masyarakat dan kebudayaannya. Berdasarkan Landasan Sosiologisantropologis Pendidikan, apabila ditinjau dari sudut pandang sosiologi, pendidikan identik dengan sosialisasi, sedangkan apabila ditinjau dari sudut pandang antropologi, pendidikan identik dengan enkulturasi. Dalam kehidupan yang riil antara sosialisasi dan enkulturasi akan sulit untuk dapat dipisahkan, sebab di dalam proses sosialisasi hakikatnya terjadi juga proses enkulturasi, sebaliknya, bahwa di dalam proses enkulturasi juga terjadi proses sosialisasi. Melalui kedua proses itu, internalisasi nilai karakter akan bekerja dengan baik jika distimulus dengan baik pula.

Karakter adalah nilai-nilai yang baik ketika seseorang tahu tentang nilai kebaikan, mau berbuat baik, nyata berkehidupan baik, dan berdampak baik terhadap lingkungan sehingga terpatri dalam diri dan terwujud dalam perilaku (Setiawati, 2017). Membangun karakter peserta didik adalah tugas pendidikan, esensinya pendidikan adalah membangun manusia seutuhnya, yaitu manusia yang baik dan berkarakter. Karakter baik perlu dibentuk dan dibina sejak dini (Mardikarini, 2016; Setiawati, 2017), membentuknya tentu tidak instan, tetapi perlu proses yang panjang melalui pengasuhan yang baik dari para pendidik. Beberapa pihak yang sangat 
mempengaruhi terbentuknya karakter anak, adalah keluarga, lingkungan masyarakat, teman sepergaulan, dan lingkungan sekolah.

Salah satu tempat pengembangan dan pendidikan karakter yang baik adalah sekolah. Pendidikan tingkat dasar menurut Sasmito (2015) merupakan akar pendidikan yang paling mendasar sehingga keberhasilan di tingkat pendidikan dasar sangat menentukan proses belajar peserta didik pada jenjang selanjutnya. Untuk itulah diperlukan proses pelaksanaan pendidikan yang baik pada jenjang pendidikan dasar.

Dunia anak yang sering diidentifikasikan dengan dunia bermain merupakan suatu masa yang sangat membahagiakan bagi anak. Dari bermain terbentuk proses sosialisasi secara dini. Sebab dalam bermain anak belajar mengenal nilai-nilai budaya dan norma-norma sosial yang diperlukan sebagai pedoman untuk berinteraksi sosial dan memainkan peran-peran sesuai dengan kedudukan sosial mereka dan dapat digunakan sebagai penentu jalan hidupnya serta pembentuk kepribadiannya (Purwaningsih, 2006).

Kegiatan bermain merupakan kegiatan yang bersifat fungsional untuk kegiatan belajar mengajar. Melalui proses enkulturasi dan sosialisasi proses internalisasi, nilai bisa diterima, dipahami, diyakini kebenarannya dan kemudian dijadikan pembimbing perilaku atau bertindak oleh peserta didik. Melalui proses sosialisasi anak akan terbiasa menerima nilai, norma, dan aturan yang berlaku dalam berinteraksi dengan induvidu maupun kelompok.

\section{Permainan Tradisional}

Pengembangan nilai-nilai karakter pada peserta didik dalam pembelajaran dapat dilakukan dengan berbagai hal. Salah satunya melalui permainan tradisional. Permainan tradisional merupakan suatu aktivitas permainan yang tumbuh dan berkembang didaerah tertentu, yang sarat dengan nilai budaya dan tata nilai kehidupan masyarakat dan diajarkan secara turun temurun ke generasi berikutnya. Permainan tradisional, secara umum memberikan kegembiraan kepada anak-anak yang melakukannya. Pada umumnya, permainan ini memiliki sifat-sifat yang universal sehingga permainan muncul di suatu daerah mungkin juga muncul di daerah lainnya, hal ini menunjukan bahwa setiap permainan tradisional yang berasal dari suatu daerah tertentu dapat juga dilakukan oleh anak-anak di daerah lainnya.

Permainan tradisional sebagai satu di antara unsur kebudayaan bangsa banyak tersebar di berbagai penjuru Nusantara, namun dewasa ini keberadaannya sudah berangsur-angsur mengalami kepunahan. Terutama bagi mereka yang saat ini tinggal di perkotaan, bahkan beberapa di antaranya sudah tak dapat dikenali lagi oleh masyarakat. Beberapa jenis permainan tradisional ada yang masih dapat bertahan, itu pun disebabkan karena para pelaku permainan tradisional tersebut berada jauh dari jangkauan permainan modern yang lebih menggunakan alat-alat canggih. Permainan tradisional sebagai salah satu bentuk kegiatan bermain diyakini dapat memberikan manfaat bagi perkembangan fisik dan mental anak. 
Banyak nilai yang dapat digali melalui permainan tradisional, adanya unsur rasa senang yang membantu perkembangan psikologis anak, hal ini dilatarbelakangi bahwa anak-anak yang melakukan permainan ini merasa terbebas dari segala tekanan, sehingga rasa keceriaan dan kegembiraan dapat tercermin pada saat anak memainkannya. Permainan tradisional juga dapat membantu anak dalam menjalin relasi sosial baik dengan teman sebayanya (peer group) maupun dengan teman yang seusianya lebih muda atau lebih tua. Permainan ini juga dapat melatih anak memanajemen konflik dan belajar mencari solusi dari permasalahan yang dihadapinya. Secara garis besar, permainan tradisional mampu mengembangkan kecakapan berfikir, melatih keberanian, melatih bersikap jujur dan sportif.

Kurniati (2011) menjelaskan bahwa permainan anak tradisional dapat mestimulasi anak dalam mengembangkan kerjasama, membantu anak menyesuaikan diri, saling berinteraksi secara positif, dapat mengkondisikan anak dalam mengontrol diri, mengembangkan sikap empati terhadap teman, menaati aturan, serta menghargai orang lain. Permainan tradisional merupakan budaya bangsa Indonesia telah terbukti dapat menumbuhkan karakter positif pada anak.

Cahyono (2011) mengemukakan permainan tradisional dapat membentuk karakter positif pada anak, memiliki karakteristik, diantaranya: Pertama, permainan tradisional cenderung menggunakan atau memanfaatkan alat atau fasilitas di lingkungan kita tanpa harus membelinya sehingga perlu daya imajinasi dan kreativitas yang tinggi. Banyak alat-alat permainan yang dibuat atau digunakan dari tumbuhan, tanah, genting, batu, atau pasir. Misalkan mobil-mobilan yang terbuat dari kulit jeruk bali, engrang yang dibuat dari bambu, permainan ecrak yang menggunakan batu, telepon-teleponan menggunakan kaleng bekas dan benang nilon dan lain sebagainya. Kedua, permainan anak tradisional melibatkan pemain yang relatif banyak. Tidak mengherankan, kalau kita lihat, hampir setiap permainan rakyat begitu banyak anggotanya. Sebab, selain mendahulukan faktor kesenangan bersama, permainan ini juga mempunyai maksud lebih pada pendalaman kemampuan interaksi antarpemain (potensi interpersonal). seperti petak umpet, congklak, dan gobak sodor. Ketiga, permainan tradisional menilik nilai-nilai luhur dan pesan-pesan moral tertentu seperti nilai-nilai kebersamaan, kejujuran, tanggung jawab, sikap lapang dada (kalau kalah), dorongan berprestasi, dan taat pada aturan. Semua itu didapatkan kalau si pemain benar-benar menghayati, menikmati, dan mengerti sari dari permainan tersebut. Dengan demikian, dapat dipahami bahwa permainan tradisional dapat memberikan dampak positif dalam mengembangkan keterampilan, sosial emosi, dan karakter anak.

\section{Pembelajaran Tematik di Sekolah Dasar}

Pandangan masyarakat bahwa pendidikan Indonesia terlalu memfokuskan/menitikberatkan aspek kognitif. Artinya siswa terlalu dibebani banyak tugas mata pelajaran sehingga tidak membentuk siswa untuk memiliki karakter. Dalam kurikulum 2013, terdapat empat kompetensi yang didalamnya memuat kompetensi religius, sosial, pengetahuan, dan keterampilan (Peraturan Menteri Pendidikan dan Kebudayaan Nomor 57 Tahun 2014). Kompetensi yang 
mengarah pada pengembangan karakater peserta didik pada proses pembelajaran ada pada kompetensi sikap religious dan sikap sosial. Karakter yang dikembangkan berdasarkan kedua kompetensi tersebut yaitu religius,jujur, disiplin, tanggung jawab, santun, peduli, dan percaya diri. Karakter tersebut dapat berkembang secara maksimal jika dalam pembelajaran juga dikembangkan nilai-nilai karakter tersebut (Mardikarini, 2016).

Pada kurikulum baru tersebut proses pembelajaran sangat memperhatikan taraf berfikir siswa yang masih utuh (holistic), sehingga itu pembelajaran dilaksanakan melalui tematik integrative (Karli, 2010) mereka belum mampu memilah-milah konsep dari berbagai disiplin ilmu dan tidak harus didrill, tetapi belajar melalui pengalaman langsung. Hal ini melukiskan cara berpikir anak yang deduktif yakni dari hal umum ke bagian-demi bagian. Oleh karena itu pembelajaran tematik integratif menjadi pembelajaran yang sesuai dengan karakteristik peserta didik di SD. Permendikbud No 67 tahun 2013 menjelaskan bahwa integrasi trans-disipliner dilakukan dengan mengaitkan berbagai mata pelajaran yang ada dengan permasalahan-permasalahan yang dijumpai di sekitar sehingga pembelajaran menjadi kontekstual. Penekanan dalam pembelajaran tematik yaitu pada penerapan konsep belajar dengan melakukan (learning by doing). Sejalan dengan pendapat Akbar (2012) bahwa pembelajaran tematik merupakan suatu sistem pembelajaran yang memungkinkan siswa (baik secara individual maupun kelompok) aktif mencari, menggali, dan menemukan konsep/prinsip keilmuan secara holistik, bermakna, dan otentik melalui tema tertentu. Jadi dengan pembelajaran tematik hasil belajar akan bertahan lebih lama

Sekolah dasar merupakan tahapan awal peserta didik belajar mengembangkan konsep-konsep yang diperlukan dalam kehidupan sehari-hari. Pada masa ini anak belajar bersosialisasi dengan teman sebaya, dan belajar menjadi pribadi yang mandiri. Usia anak SD merupakan usia emas dimana anak memiliki sensitivitas yang tinggi terhadap penerimaan segala pengaruh perkembangan, hal ini disebabkan karena kepekaan yang dimiliki anak akan lebih berkembang optimal jika diberikan pada masa ini. Untuk itu proses pembelajaran harus bersifat kontekstual sesuai dengan dunianya dan disajikan secara terintegrasi dan tidak parsial.

\section{Enkulturasi Nilai Karakter Melalui Permainan Tradisional Pada Pembelajaran Tematik di SD}

Penanaman nilai-nilai karakter sangat penting dimulai sejak usia dini dalam membentuk kepribadian dan akhlak mulia pada diri anak. Usia sekolah dasar merupakan masa dimana anak mulai menerima internalisasi nilai yang diajarkan orang dewasa. Proses sosialisasi dan enkulturasi adalah masa dimana seorang anak belajar tentang lingkungan dan budayanya dalam pendidikan formal, informal, maupun nonformal. Melalui proses itu nilai karakter akan tumbuh pada diri anak. Sudah sepatutnya pendidikan karakter dimulai dari dalam keluarga, sebagai lingkungan pertama bagi pertumbuhan karakter anak. Setelah keluarga, sudah menjadi ajaran wajib peserta didik dimulai di sekolah dasar. Sekolah sebagai 
lembaga pendidikan adalah wahana terbaik dan paling efektif yang memungkinkan peserta didik menyerap nilai-nilai karakter yang diajarkan selama berinteraksi sosial karena lembaga pendidikan merupakan sarana proses transmisi norma-norma dan nilai budaya. Sejatinya dengan pendidikan (Juanda, 2010) membantu peserta didik mengembangkan kreativitasnya, kesadaran etis serta bersosialisasi dengan normanorma, nilai-nilai, dan keyakinan yang baik.

Banyak sekali makna tersirat yang mungkin kita tidak sadari dari permainan tradisional sebagai warisan leluhur, nilai-nilai itu pula yang otomatis diterima oleh dunia anak ketika anak masih kecil. Upaya mengembalikan dan mengenalkan permainan tradisional kepada anak-anak di tengah perkembangan dan kemudahan teknologi adalah sebuah keharusan. Tugas pendidikan formal harus mampu menyeimbangkan perkembangan teknologi dengan budaya local. Untuk itu pembelajaran di sekolah diharapkan tidak hanya bersifat teoritik tetapi juga dapat menggunakan sumber belajar lingkungan dengan menggunakan permainan tradisonal, karena dalam permainan tradisional mempunyai nilai-nilai pengetahuan yang seharusnya dilestarikan oleh guru.

Menginternalisasi nilai melalui permainan tradisional pada peserta didik harus memperhatikan aspek-aspek budaya dalam penyajian materi setiap mata pelajaran yang disesuaikan dengan budaya Indonesia. Bentuk enkulturasi yang diharapkan adalah bagaimana peserta didik mampu belajar memahami, mengadaptasi pola pikir, pengetahuan, dan kebudayaan yang dipelajarinya melalui permainan tradisional yang disuguhkan dalam pembelajaran secara tematik.

Selama diberlakukannya Kurikulum 2013 di tingkat sekolah dasar, permainan tradisional hanya dilaksakan pada muatan local dan Pendidikan Jasmani dan Olah Raga (Anggoro, 2016). Tidak menutup kemungkinan bahwa permainan tradisional bisa dilakukan dalam pembelajaran tematik melalui muatan pembelajaran IPA, IPS, PKn, Penjas OR, Bahasa Indonesia. bahkan muatan Matematika. Sehingga proses enkulturasi nilai karakter dapat dipelajari by design dan dimanfaatkan oleh guru sebagai bentuk pelestarian budaya atau proses transmisi budaya kepada peserta didik. Tema-tema penting dalam masing-masing muatan pelajaran harus sesuai dengan jenis permainan yang akan dipilih. Sesuai dengan karakteristiknya (Madjid, 2014) tematik memiliki keistimewaan jika digunakan dalam pembelajaran, tema yang di angkat harus actual, dan dekat dengan dunia siswa, memilih materi dari beberapa mata pelajaran yang saling terkait, tidak boleh bertentangan dengan kurikulum yang berlaku, memadukan beberapa mata pelajaran dalam satu tema, dan tidak boleh dipaksakan ada kaitan satu sama lain.

Proses enkulturasi akan berjalan maksimal jika didukung oleh kekuatan nilai karakter yang ada dalam permainan tradisional melalui pembelajaran tematik, juga memperhatikan karakteristik peserta didik. Peserta didik SD masih senang bermain, rasa ingin tahu yang tinggi, dan berfikir operasional kongkrit (Karli, 2010), senang bergerak, senang bekerja dalam kelompok, dan senang merasakan/ melakukan sesuatu secara langsung, sehingga guru harus kreatif mengembangkan pembelajaran 
yang mengandung unsur permainan, memungkinkan peserta didik berpindah atau bergerak dan bekerja atau belajar dalam kelompok serta memberikan kesempatan kepada peserta didik terlibat langsung dalam pembelajaran. Havighurst menjelaskan bahwa tugas perkembangan anak usia SD sudah menguasai keterampilan fisik yang diperlukan dalam permainan dan aktivitas fisik. Sehingga tugas guru adalah menciptkan lingkungan teman sebaya yang mengajarkan keterampilan fisik, melaksanakan pembelajaran yang memberikan kesempatan kepada peserta didik untuk belajar bergaul dan bekerja dengan teman sebaya sehingga kepribadian sosialnya berkembang, mengembangkan kegiatan pembelajaran yang memberikan pengalaman yang kongkret dan langsung dalam membangun konsep, dan melaksanakan pembelajaran yang dapat mengembangkan nilai-nilai karakter sehingga peserta didik mampu menjalani proses enkulturasi nilai karakter yang disajikan oleh guru.

\section{Simpulan}

1. Proses enkulturasi nilai karakter dalam permainan tradisional yang didesain melalui tematik integrative diharapkan akan melatih karakter jujur, sportif, mentaati aturan, mengontrol diri, menghargai orang lain, membantu anak dalam menjalin relasi sosial baik dengan teman sebayanya (peer group) maupun teman beda usia, dapat melatih memanajemen konflik, belajar mencari solusi dari permasalahan, mampu mengembangkan kecakapan berfikir, melatih keberanian, dapat mestimulasi anak dalam mengembangkan kerjasama, membantu anak menyesuaikan diri, saling berinteraksi secara positif, dan mengembangkan sikap empati terhadap teman.

2. Pembelajaran tematik merupakan suatu sistem pembelajaran yang memungkinkan siswa aktif mencari, menggali, dan menemukan konsep/prinsip keilmuan secara holistik, bermakna, dan otentik melalui tema tertentu dan hasil belajar akan bertahan lebih lama. Pembelajaran Tematik akan memberikan keleluasaan kepada guru untuk mengembangkan kreatifitasnya dalam mengembangkan bahan ajar, menentukan sumber dan media belajar, termasuk memasukkan permainan tradisional dalam tematema tertentu dalam muatan pembelajaran.

3. Dengan memperhatikan karakteristik peserta didik usia sekolah dasar, guru harus kreatif dalam mengembangkan pembelajaran yang mengandung unsur permainan, menciptakan lingkungan teman sebaya yang mengajarkan keterampilan fisik, bersosialisasi, bekerjasama, kontekstual, dan mampu mengembangkan nilai-nilai karakter selama proses pembelajaran.

\section{Daftar Pustaka}

Ainissyifa, Hilda. (2014). Pendidikan Karakter dalam Perspektif Pendidikan Islam. Jurnal Pendidikan Universitas Garut Vol. 08; No. 01; 2014; 1-26 ISSN: 1907-932X 
Anggoro, Subuh. (2016). Gotong Royong Dalam Permainan Tradisional Gobak Sodor. Prosiding Seminar nasional Etnopedagogik. Kajian Nilai-Nilai Etnokultur Sebagai landasan Pendidikan. Bandung. Insan Mulia. ISBN.978-602-74162-1-5

Ariyanti, Puput. (2017). Manajemen Pembelajaran Dengan Menggunakan Pendekatan Tematik Integratif Di Sd Negeri Tugu Kecamatan Purwoasri Kediri. Jurnal Manajemen Pendidikan. Volume 01 Nomor 01 Tahun 2017, $0-9$.

Artobatama, Irman. (2018). Pembelajaran Stem Berbasis Outbound Permainan Tradisional. Indonesian Journal of Primary Education Vol. 2, No. 2 (2018) 40-47 ISSN: 2597-4866.

Cahyono, N. 2011. "Permainan Tradisional Anak. Berteknologi Tapi tetap Berbudaya". https://permata-nusantara.blogspot.com/2010/12/permainananak-tradisional.html. Diakses pada tanggal 15 Agustus 2019.

Juanda. (2010). Peranan Pendidikan Formal Pada Proses Pembudayaan. Lentera Pendidikan Vol 13 No 1. 1 Juni 2010.hal 1-15.

Karli, Hilda. (2010). Penerapan Pembelajaran Tematik di Indonesia. Jurnal Pendidikan dasar Eduhumaniora. Vol 2. No 1. Januari 2010. ISSN: 2579 5457.

Kurniawan, M. I. (2015). Tri Pusat Pendidikan Sebagai Sarana Pendidikan Karakter Anak Sekolah Dasar. Journal Pedagogia, 4(1), 41-49.

Koentjaraningrat. (1996). Kebudayaan, Mentalitas, dan Pembangunan. Jakarta. Gramedia Pustaka Utama.

Kurniati, E. 2011. Program Bimbingan untuk Mengembangkan Keterampilan Sosial Anak Melalui Permainan Tradisional. Surakarta: Skripsi Universitas Muhammadiyah Surakarta. Tidak diterbitkan

Muhtar, T. (2014). Analisis Kurikulum 2013 Ditinjau dari Aspek Nilai Karakter Bangsa. Mimbar Sekolah Dasar, 1(2), 168-175.

Mardikarini, Sasi. Suwarjo. (2016). Analisis Muatan Nilai-Nilai Karakter Pada Buku Teks Kurikulum 2013 Pegangan Guru Dan Pegangan Siswa. Jurnal Pendidikan Karakter, Tahun VI, Nomor 2, Oktober 2016. 261-275.

Maryani, E; Syamsudin, H. (2009). Pengembangan Program Pembelajaran IPS Untuk Meningkatkan Kompetensi Keterampilan Sosial. Jurnal Penelitian Vol., 9 Nomor 1(1), 1-111.

Madjid, Abdul. (2014). Strategi Pembelajaran. Bandung. PT Remaja Rosdakarya. Pramudyani, Avanti Vera Risti. Dkk (2017). Kurikulum Holistik Integratif Berbasis Permainan Tradisional Pada PAUD Di Yogyakarta. Jurnal Penelitian Ilmu Pendidikan Volume 10, Nomor 2, September 2017. 86-96

Purwaningsih, Ernawati. (2006). Permainan Tradisional Anak: Salah Satu Khasanah Budaya yang Perlu Dilestarikan. Jurnal Jantra Vol. I, No. 1, Juni 2006. 40-46. ISSN: ISSN 1907 - 9605

Satya, V. E. (2018). Strategi Indonesia Menghadapi Industri 4.0. Pusat Penelitian Badan Keahlian DPR RI, X(9).

Sartini, S. (2004). Menggali Kearifan Lokal Nusantara: Sebuah Kajian Filsafati. Jurnal Filsafat, 14(2), 111- 120. 
Setiawati, Nanda Ayu. (2017). Prosiding Seminar Nasional Tahunan Fakultas Ilmu Sosial Universitas Negeri Medan Tahun 2017 Vol. 1 No. 1 2017, Hal. 348352. ISSN: 2598-3237 (media cetak) ISSN: 2598-2796 (media online).

Sasmito, L. \& Mustadi, A. 2015. "Pengembangan Lembar Kerja Peserta Didik Tematik Integratif Berbasis Pendidikan Karakter pada Peserta Didik Sekolah Dasar". Jurnal Pendidikan Karakter, Vol. V, No. 1, hlm. 67-79.

Peraturan Presiden No 87 Tahun 2017 Tentang Penguatan Pendidikan Karakter Peraturan Menteri Pendidikan dan Kebudayaan Nomor 57 Tahun 2014 Permendikbud No 20 tahun 2018 Tentang Penguatan Pendidikan Karakter 